\title{
Accounting Information, the Cost of Capital and Excess Stock Returns: The Role of Earnings Quality-Evidence from Panel Data
}

\author{
Nicholas Apergis (Corresponding author) \\ Department of Banking \& Financial Management, University of Piraeus, Greece \\ Tel: 30-210-414-2429 E-mail: napergis@unipi.gr
}

George Artikis

Department of Business Administration, University of Piraeus, Greece

E-mail: gartikis@unipi.gr

Sofia Eleftheriou

Department of Business Administration, University of Piraeus, Greece

E-mail: sofelef@unipi.gr

John Sorros

Department of Business Administration, University of Piraeus, Greece

E-mail: sorros@unipi.gr

Received: November 9, 2011

Accepted: November 29, 2011

Published: February 1, 2012

doi:10.5539/ibr.v5n2p123

URL: http://dx.doi.org/10.5539/ibr.v5n2p123

\begin{abstract}
This paper investigates the impact of the firm's accounting information and, especially the role of earnings quality, on its cost of capital and how this influences excess returns. The analysis extends prior works by investigating how components of accounting information and, especially earnings quality, affect stock returns through their effect on the cost of capital. The empirical approach uses a sample of US manufacturing firms as well as the methodology of panel data. The empirical findings display that all components of accounting information affect the firm's cost of capital, which, in turn, exerts a negative effect on the firm's excess returns, an empirical documentation not captured in case that the analysis links directly the cost of capital and excess returns.
\end{abstract}

Keywords: Accounting information, Cost of capital, Excess returns, Earnings quality, US manufacturing, Panel data

\section{Introduction}

Recent research attempts in finance have established that asymmetric information poses risk to uninformed investors and, therefore, should be priced (Easley and O'Hara, 2004; Easley et al., 2002). According to this argument, uninformed traders bear trading costs from trading with insiders (Speigel and Subrahmanyam, 1992). Therefore, those uninformed traders require a premium to invest in risky assets when facing the prospect that they may be trading with informed traders in a multi-asset context where traders plan to diversify their holdings. Aboody and Lev (2000) argue that insiders of research and development intensive firms trade on private information, but without relating inside trading to the pricing of asymmetric information. Earnings quality is viewed as a broader measure of asymmetric information. Dow and Gorton (1995) provide an analysis that relies on restrictions on uninformed traders' ability to hold the market portfolio. Amihud and Mendelson (1986) argue that asymmetric information leads to higher transaction costs in the form of bid-ask spreads. Those spreads imply lower prices given that investors are interested in returns after transaction costs, while these costs cannot be diversified away. Baiman and Verrecchia (1996) link the cost of capital to public earnings disclosures and inside trading. Their findings show that although increased public disclosure reduces the cost of capital, it may also lead to less efficient production and compensation. In addition, Beneish and Vargus (2002) investigate the association between accruals and inside trading. Their results raise the question whether the accruals anomaly alone could be capable of accounting for the presence of 
asymmetric information risk. Finally, Aboody et al. (2005) examine whether abnormal accruals can proxy for asymmetric information that affect the cost of capital. They find that earnings quality is indeed an important pricing factor for the value of firms.

This study, based on theoretical arguments claiming that information risk, i.e. the likelihood that information pertaining to a firm's environment is considered of poor quality by investors, is a non-diversifiable risk factor (Easley and O'Hara, 2004; Ecker et al., 2006), plans to examine how earnings quality affects investor's reliance on the above link. Firms with poor earnings quality have higher costs of capital. The ultimate objective is to increase the extent that managers' private information for future profitability is impounded in financial aggregates, such as stock prices. In addition, regulator's interest on management discussion and analysis sections in the annual reports is growing responding to the global consensus that narrative communication is the step forward in improving the quality of corporate reporting. Managers may release overly optimistic views about their firm's earnings to maximize the value of their stock options and thus to reduce the likelihood of bankruptcy or hostile takeovers or even to reduce the cost of new equity capital. Therefore, viewing earnings quality as a proxy for the credibility of the earnings signal emanating from the financial statements, this study will investigate whether investors assess the quality of reported earnings to infer the credibility of their disclosures. Such disclosures refer to information on current plans and forecasts that enable shareholders, investors and financial analysts to assess a firm's financial performance (especially, for the future). It mainly involves risks and uncertainties that could have a negative impact on actual results and cause them to deviate significantly from expected results.

Prior research efforts have shown that the ability of the stock market to anticipate future earnings is positively associated with the number of disclosed statements in annual reports (Hussainey et al., 2003). When it comes to investors, earnings quality becomes an important signal of management's credibility. Analytical research provides conflicting predictions about how earnings quality affects the firm's excess stock returns. A research avenue argues that firms with poor earnings quality issue more expansive disclosures as information asymmetry is greater for these firms (Verrecchia, 1983). By contrast, other research attempts focus on the endogenous nature of disclosures and show that firms with good earnings quality provide more expansive disclosures as they possess higher quality insider information and investors regard their disclosures as more credible (Dye, 1985; Verrecchia, 1990).

The goal of this paper is to empirically investigate the impact of the firm's accounting information and particularly the role of earnings quality as a part of accounting information, on its cost of capital as well as how the latter influences excess or abnormal returns. This analysis followed in this paper has certain novelties: First, it extends prior works, as the above, on the issue by investigating how earnings quality and other components of accounting information affect stock prices through their direct effect on the cost of capital, second, it makes use of a large sample of US manufacturing firms, while it makes use, for the first time in this literature, of the methodology of panel data to investigate the above effect. There are at least three factors contributing to the extensive growth of panel data estimations: data availability, greater capacity for modeling the complexity of economic and financial trends, e.g. controlling the impact of omitted variables and uncovering dynamic relationships, than single cross-section or time series data estimations and challenging methodology (Baltagi, 2001; Hsiao, 2003). A key novel feature of this research design is that it accommodates the role of earnings quality as a part of accounting information to investigate, for the first time, its impact on the link between the cost of capital and excess stock returns.

The findings should be of interest to managers, market participants, policy makers and regulators. For managers the results should recommend that there is a benefit to maintaining a high quality reporting system, i.e. when firms report high quality profits, the market is highly responsive to information included in the annual reports. This is also of interest to individual investors and analysts in assessing the potential risks involved when relying on such disclosures. The results should also be relevant for policy makers and regulators. The greatest risk that regulators face is that managers may make self-serving disclosures and mislead investors. Investors mitigate such risk by conditioning their reliance on the firm's reported earnings quality. Finally, the results should be extensively important for the literature of accounting choice, i.e. the research on financial reporting and disclosure choices as well as capital market consequences. In particular, both financial reporting and disclosure strategies are driven by the firm's information environment, managerial incentives and corporate financing. These choices also interact, inducing investors to extract useful information from earnings quality. By shedding light on these interactive effects and their consequances for investor decision making, the empirical findings should highlight the need for examining the firm's policies not in isolation but as a part of a general reporting and disclosure equilibrium.

The remainder of this paper is organized as follows. Section 2 discusses explicitly the role of earnings quality in the literature of stock markets, while Section 3 discusses the data used along with methodological issues and the 
construction of earnings quality measurement. Section 4 presents the empirical analysis, while Section 5 concludes the paper and provides some policy implications and suggestions for further research.

\section{The Role of Earnings Quality for Stock Markets}

Recent studies make use information from both sides of the balance sheet, i.e. assets and liabilities, to assess the value-relevance of accounting information for stock prices (Ohlson, 1995). Previous works have also examined such link through the concept of market liquidity. In particular, studies by Baiman and Verrecchia (1996) and Easley and O'Hara (2004) suggest an indirect link between accounting information and the firm's cost of capital based on market liquidity and adverse selection.

Many studies have attempted to address directly the impact of information accounting on stock prices, both for the cases of the US and the UK and for various global capital markets (Beaver et al., 1979; Amir et al., 1993; Barth and Clinch, 1996; Chan and Seow, 1996; Graham and King, 1998). Others have focused on examining the link between stock returns and earnings for various US firms (Collins, et al., 1989; Hayn, 1995), while Barth et al. (1998) and Burgstaher and Dichev (1997) give emphasis on the joint role of assets and liabilities, in addition to earnings, for the course of stock prices. Alford et al. (1993) applies this analysis for firms outside in the US and particularly in Ausralia, France, the Netherlands and the UK. Their results reach the same conclusions.

Whether investors rely on the quality of reported earnings to assess the credibility of their announcements depends on how earnings quality affects the likelihood of such disclosures in the annual reports. Verrecchia (1983) argues that firms with poor earnings quality face higher information asymmetry and, thus, issue more expansive disclosures as the incremental value of such disclosures is greater for these firms. Managers would need to operate a high quality reporting system to be able to provide disclosures that investors would view as credible. Verrecchia (1990) proposes that high information quality implies a lower threshold level and, thus, a higher likelihood of such disclosures, as investors would treat such disclosures as more credible. The rationale here is that as earnings quality increases, the market exerts more pressure to managers to disclose information by discounting the firm's value if information is withheld. This implies a positive association between such disclosures and earnings quality. Verrecchia (1990) also notes for this point that such a positive association may not be unequivocal, due to the indirect effect of the quality of disclosures. In other words, higher quality information can reduce the market uncertainty and, thus, the incremental value of disclosures and their probability, consistent with a substitute association. Fama and French (1996) also argue that firms with high magnitudes of earnings quality, measured as signed abnormal accruals, earn positive risk-adjusted returns and vice verasa. Their results receive statistical support by Chan et al. (2001) and Xie (2001). Cohen (2003) explores the impact of exogenous variables on reporting quality as well as on its economic implications. He provides evidence in favor of the fact that reporting quality has significant effects on the cost of equity capital.

Empirical attempts probing the association between disclosures and earnings quality provide evidence consistent with both a substitutive and a complementary relation, depending on the disclosure and earnings quality strategy chosen. Francis et al. (2008) find a complementary association between the disclosure score and earnings quality. When focusing on the score component relating to the firm's projected information, they find no evidence of a significant association with earnings quality. Imhoff (1978) finds that firms issuing earnings forecasts have less volatile earnings than non-forecast firms. Waymire (1985) argues that firms issuing earnings forecasts more frequently have less volatile earnings relative to firms issuing such projections on an infrequent basis. Lang and Lundholm (1993) find that firms' ratings are decreasing in the correlation between earnings and returns, a finding that is consistent with firms with less informative financial statements providing additional disclosures. In the same fashion, Finally, Demers and Vega (2009) find that net optimism detected in soft information that managers disclose in earnings announcement is priced more for firms with lower quality accounting data, a finding that is consistent with net optimism substituting for poor earnings quality.

\section{Data}

The firm level data sample covers a selected group of US firms. Our sample (based on quarterly data) comes from Bloomberg and Compustat. In case those firms have missing values for any of our variables under investigation are dropped. As a result, 2830 firms have been employed spanning the period January 1990-June 2009, yielding a total of 56600 observations. Variables such as the beta risk factor (b), the book value (bv) and earnings per share (eps) are used to proxy accounting information with respect to equity cost of capital, while variables such as financial leverages (flev) and interest coverage (intcov) are used to proxy accounting information with respect to debt cost of capital. Financial leverage is measured as the firm's ratio of interest-bearing debt to total assets, while interest coverage is measured as the fir,'s ratio of operating income to interest expenses. Finally, stock prices (p) are also obtained. This data set is also obtained from Bloomberg. For the empirical goals of the analysis the weighted cost of 
capital was calculated through equation (1) described above. To this end, data on the cost of long-term debt, the firm's marginal income tax rate, the cost of common stock, and the weights of long-term debt and common stock in the firm's capital structure, are also obtained from Bloomberg. When determining the weights of debt and equity, we use their market values rather than book values for reasons mentioned above. Data on the three-month T-bills rate (rf) was also obtained from Bloomberg. In this manner, excess returns (er) are calculated simply by substracting rf from percentage differences in stock prices. Finally, the RATS (version 6.1) software assists the empirical analysis.

\subsection{Measures of Earnings Quality}

Our four proxies for earnings quality (EQ) are recommended by the accounting literature (Francis et al., 2002). The first two measures are variants based on Jones' (1991) separation of accruals into a normal component that can be justified by sales and investments and an abnormal component. We will also use the unsigned magnitude of abnormal accruals as a measurement of earnings quality. Thus, the third and fourth measures of earnings quality are based on Dechow and Dichev's (2002) model of working capital accruals that separate total working capital accruals into an explained portion correlated with past, current or future cash flows and an abnormal portion. Then, earnings quality measures are derived from the unsigned magnitude of abnormal working capital accruals. The above four definitions are measures of the precision of public disclosure. In other words, higher quality means higher precision of public disclosure, implying less remaining private information from which privately informed traders exctract gains. Francis et al. (2002) find that the first two measures are negatively correlated to anticipated stock returns.

For the empirical purposes of this study four earnings quality measures are employed from Aboody et al. (2005). All four measures rely on accounting fundamentals to the separate accruals into non-discretionary (normal) and discretionary (abnormal) components. Earnings quality is defined as the absolute value of the abnormal component. The larger the absolute value, the lower is earnings quality. In particular, total accruals (TA), total current accruals (TCA) and cash flows (CFs) for each firm $\mathrm{j}$ and year $\mathrm{t}$ are calculated as follows:

$$
\begin{gathered}
\mathrm{TA}_{\mathrm{jt}}=\Delta \mathrm{CAS}_{\mathrm{jt}}-\Delta \mathrm{CL}_{\mathrm{jt}}-\Delta \mathrm{CASH}_{\mathrm{jt}}+\Delta \mathrm{STDEBT}_{\mathrm{jt}}-\mathrm{DEPN}_{\mathrm{jt}} \\
\mathrm{TCA}_{\mathrm{jt}}=\Delta \mathrm{CAS}_{\mathrm{jt}}-\Delta \mathrm{CL}_{\mathrm{jt}}-\Delta \mathrm{CASH}_{\mathrm{jt}}+\Delta \mathrm{STDEBT}_{\mathrm{jt}} \\
\mathrm{CF}_{\mathrm{jt}}=\mathrm{NIBE}_{\mathrm{jt}}-\mathrm{TA}_{\mathrm{jt}}
\end{gathered}
$$

where:

$\mathrm{TA}=$ total accruals, $\mathrm{TCA}=$ total current accruals, $\mathrm{CF}=$ cash flows from operation, $\mathrm{CAS}=$ current assets, $\mathrm{CL}=$ current liabilities, $\mathrm{CASH}=$ cash, STDEBT $=$ short-term debt, DEPN $=$ depreciation expenses, NIBE $=$ net income before extraordinary items and $\Delta=$ changes from year $\mathrm{t}-1$ to year $\mathrm{t}$. To estimate abnormal total accruals, the following regression is performed:

$$
\mathrm{TA}_{\mathrm{jt}} / \text { Asset }_{\mathrm{j}(\mathrm{t}-1)}=\mathrm{a}_{1} 1 / \operatorname{Asset}_{\mathrm{j}(\mathrm{t}-1)}+\mathrm{a}_{2} \Delta \mathrm{REV}_{\mathrm{jt}} / \text { Asset }_{\mathrm{j}(\mathrm{t}-1)}+\mathrm{a}_{3} \mathrm{PPE}_{\mathrm{jt}} / \text { Asset }_{\mathrm{j}(\mathrm{t}-1)}+\varepsilon_{\mathrm{jt}}
$$

where:

Asset $=$ total assets, REV $=$ revenues, $\mathrm{PPE}=$ gross value of property, plant and equipment and $\varepsilon$ is a residual term. Next, we make use of the above parameter estimates to get normal accruals (NA) as:

$$
\mathrm{NA}_{\mathrm{jt}}=\hat{\mathrm{a}}_{1} 1 / \text { Asset }_{\mathrm{j}(\mathrm{t}-1)}+\hat{\mathrm{a}}_{2}\left(\Delta \mathrm{REV}_{\mathrm{jt}}-\Delta \mathrm{AR}_{\mathrm{jt}}\right) / \text { Asset }_{\mathrm{j}(\mathrm{t}-1)}+\hat{\mathrm{a}}_{3} \mathrm{PPE}_{\mathrm{jt}} / \operatorname{Asset}_{\mathrm{j}(\mathrm{t}-1)}
$$

where: $\triangle \mathrm{AR}=$ accounts receivable. Finally, abnormal accruals (AA) are defined as:

$\mathrm{AA}_{\mathrm{jt}}=\mathrm{TA}_{\mathrm{jt}} / \mathrm{Asset}_{\mathrm{j}(\mathrm{t}-1)}-\mathrm{NA}_{\mathrm{jt}}$. The absolute value of abnormal accruals is the first measure of earnings quality, let be EQ1, with larger values indicating lower earnings quality.

Next, similar to total accruals, we can estimate abnormal current accruals using the following regression:

$$
\mathrm{TCA}_{\mathrm{jt}} / \text { Asset }_{\mathrm{j}(\mathrm{t}-1)}=\mathrm{c}_{1} 1 / \text { Asset }_{\mathrm{j}(\mathrm{t}-1)}+\mathrm{c}_{2} \Delta \mathrm{REV}_{\mathrm{jt}} / \text { Asset }_{\mathrm{j}(\mathrm{t}-1)}+\eta_{\mathrm{jt}}
$$

where: $\eta=$ a residual term. Again, we make use of the above coefficient estimates to calculate normal current accruals:

$$
\mathrm{NCA}_{\mathrm{jt}}=\hat{\mathrm{c}}_{1} 1 / \mathrm{Asset}_{\mathrm{j}(\mathrm{t}-1)}+\hat{\mathrm{c}}_{2}\left(\Delta \mathrm{REV}_{\mathrm{jt}}-\Delta \mathrm{AR}_{\mathrm{jt}}\right) / \operatorname{Asset}_{\mathrm{j}(\mathrm{t}-1)}
$$

and we calculate the abnormal component as:

$\mathrm{ACA}_{\mathrm{jt}}=\mathrm{TCA}_{\mathrm{jt}} / \mathrm{Asset}_{\mathrm{j}(\mathrm{t}-1)}-\mathrm{NCA}_{\mathrm{jt}}$. The absolute value of the abnormal current accruals is the second measure of earnings quality, let it be EQ2. Similarly, larger values of EQ2 imply poorer earnings quality.

To get the third measure of earnings quality we make use estimates of total current accruals based on cash flows from operations:

$$
\mathrm{TCA}_{\mathrm{jt}} / \mathrm{AvAsset}_{\mathrm{jt}}=\mathrm{g}_{0}+\mathrm{g}_{1} \mathrm{CF}_{\mathrm{j}(\mathrm{t}-1)} / \operatorname{AvAsset}_{\mathrm{jt}}+\mathrm{g}_{2} \mathrm{CF}_{\mathrm{jt}} / \text { AvAsset }_{\mathrm{jt}}+\mathrm{g}_{3} \mathrm{CF}_{\mathrm{j}(\mathrm{t}+1)} / \text { AvAsset }_{\mathrm{jt}}+\theta_{\mathrm{jt}}
$$


where: AvAsset $=$ average total asset over years $\mathrm{t}-1$ and $\mathrm{t}$ and $\theta=$ a residual term. The absolute value of residuals $\theta$ is the third definition of earnings quality, let it be EQ3, while the time-series standard deviation of those residuals is the fourth definition of earnings quality, let it be EQ4. By the same standards, larger absolute residuals and larger standard deviations of residuals imply lower earnings quality.

\section{Empirical Analysis}

\subsection{Panel Unit Root Tests}

At the outset, the statistical properties of value added, the capital stock, labor and depreciation expenses are examined by testing for the presence of unit roots. There are a variety of panel unit root tests, which include Maddala and $\mathrm{Wu}$ (1999), Hadri (2000), Levin et al. (LLC, 2002) and Im et al. (IPS, 2003).

The results in Table 1 point out that the hypothesis that all the variables, except the weighted cost of capital (wacc), the earnings per share ratio (eps) and excess returns (er), under study contain a unit root is accepted at the $1 \%$ significant level in all tests, suggesting that these variables are I(1), while the variables wacc, wacc1, wacc2, wacc3, wacc4, TA/Asset, $\triangle \mathrm{REV} /$ Asset, PPE/Asset, TCA/Asset, TCA/AvAsset, CF/AvAsset, EQ1, EQ2, EQ3 and EQ4 are $\mathrm{I}(0)$. These findings reject the presence of cointegation.

\section{Insert Table 1 Here}

\subsection{Dynamic Heterogeneity}

An issue that it is of major concern is the heterogeneity of the firms included in this data set. In particular, through time and across firms, the effects of accounting information-wacc relationship as well as that of the wacc-excess stock returns relationship. In the statistical framework of this study we first test for heterogeneity and then by controlling for it through appropriate techniques (Holtz-Eakin, 1986; Holtz et al., 1985). The dynamic heterogeneity, i.e. variation of the intercept over firms and time, across a cross-section of the relevant variables can be investigated as follows. In the first step, an ADF (n) equation for each relationship in the panel is estimated; then, the hypothesis of whether regression parameters are equal across these equations is tested. Next, a similar test of parameter equality is performed by estimating a n-order autoregressive model for each of the relationships under investigation. Standard Chow-type $\mathrm{F}$ tests under the null of parameter equality across all relationships are also performed. Heterogeneity in cross-sectional parameters is indicated if the results reject the null hypothesis. Finally, homogeneity error variance across groups is also examined as another measure of dynamic heterogeneity. White's tests for group-wise heteroscedasticity are employed to serve this objective. The results of this procedure are reported in Table 2. In all specifications the empirical findings indicate that the relationships under investigation are characterized by heterogeneity of dynamics and error variance across groups, supporting the employment of panel analysis.

\section{Insert Table 2 Here}

\subsection{Panel Regression Estimates}

The first part of this sub-section reports the estimates of equations (2), (3) and (4). A classic problem in such estimations is the simultaneous equation bias and the identification problem. A solution to this problem, recommended by Arellano and Bond (1991), is to exploit the orthogonality that is present between the lagged values of the dependent variable and the error term. This procedure makes use of lagged differences and lagged levels beyond $\mathrm{t}-2$ as instruments for the lagged dependent variable. The orthogonality or 'exogeneity' of the instrument set can be tested using the GMM-J-statistic to compute the familiar Sargan (1958) test. In particular, these estimates for equation (2) -the estimates for normal accruals- yield:

$$
\begin{gathered}
\mathrm{NA}_{\mathrm{jt}}=-0.662 \Delta\left(1 / \mathrm{Asset}_{\mathrm{j}(\mathrm{t}-1)}\right)+0.036\left(\Delta \mathrm{REV}_{\mathrm{jt}} \Delta \mathrm{AR}_{\mathrm{jt}}\right) / \mathrm{Asset}_{\mathrm{j(t-1)}}+0.027 \mathrm{PPE}_{\mathrm{jt}} / \mathrm{Asset}_{\mathrm{j}(\mathrm{t}-1)} \\
(-12.4)^{*} \quad(15.66)^{*} \quad(8.28)^{*} \\
\mathrm{R}-\mathrm{bar}^{2}=0.48 \mathrm{LM}=1.55[0.36] \text { RESET}=2.76[0.38] \mathrm{HE}=1.42[0.38] \mathrm{J} \text {-test }=34.56[0.00]
\end{gathered}
$$

Figures in parentheses denote t-statistics, while those in brackets denote p-values. LM is a serial correlation for the residuals test, RESET is a model specification test, HE is a heteroskedasticity test, J-test is the Sargan instruments validity test and an asterisk denotes statistical significance at $1 \%$. The estimates for equation (3) -the estimates for normal current accruals- yield:

$$
\begin{aligned}
& \mathrm{NCA}_{\mathrm{jt}}=0.329 \Delta\left(1 / \text { Asset }_{\mathrm{j}(\mathrm{t}-1)}\right)+0.024\left(\Delta \mathrm{REV}_{\mathrm{jt}}-\Delta \mathrm{AR}_{\mathrm{jt}}\right) / \text { Asset }_{\mathrm{j}(\mathrm{t}-1)} \\
& (18.7)^{*} \quad(20.8)^{*} \\
& \mathrm{R}^{-b^{2}}{ }^{2}=0.74 \mathrm{LM}=1.32[0.30] \text { RESET }=2.47[0.31] \mathrm{HE}=1.49[0.42] \mathrm{J} \text {-test }=37.23[0.00]
\end{aligned}
$$

Finally, the estimates of equation (4) -the estimates of total current accruals based on cash flows- yield: 


$$
\begin{aligned}
& \mathrm{TCA}_{\mathrm{jt}} / \mathrm{AvAsset}_{\mathrm{jt}}=0.012-0.055 \mathrm{CF}_{\mathrm{j}(\mathrm{t}-1)} / \mathrm{AvAsset}_{\mathrm{jt}}+0.083 \mathrm{CF}_{\mathrm{jt}} / \mathrm{AvAsset}_{\mathrm{jt}}- \\
& (3.71)^{*} \quad(-5.52)^{*} \quad(6.78)^{*} \\
& 0.089 \mathrm{CF}_{\mathrm{j}(\mathrm{t}+1)} / \text { AvAsset }_{\mathrm{jt}} \\
& (-14.2)^{*} \\
& \mathrm{R}_{-} \mathrm{bar}^{2}=0.45 \mathrm{LM}=1.21[0.22] \mathrm{RESET}=2.41[0.32] \mathrm{HE}=1.45[0.39] \mathrm{J} \text {-test }=39.06[0.00]
\end{aligned}
$$

Table 3 reports a correlation matrix based on Spearman and Pearson correlation tests. The correlation findings display that the first two measures, EQ1 and EQ2 -based on both tests- have a very strong correlation between them. Although the correlations between EQ3 and EQ4 are lower than before, they still display a high association between them. These findings could be an indication that the first two measures capture similar things about the structure of a firm, a characteristic that seems to be weaker for the remaining two measures.

Insert Table 3 Here

The fixed-effect panel relationship between cost of capital, beta, book value, earnings per share, the price earings ratio, financial leverage, interest coverage and earnings quality is specified as follows:

$$
\operatorname{wacc}_{\mathrm{jt}}=\alpha_{\mathrm{jt}}+\beta_{1 \mathrm{j}} \Delta \mathrm{b}_{\mathrm{jt}}+\beta_{2 \mathrm{j}} \Delta \mathrm{bv}_{\mathrm{jt}}+\beta_{3 \mathrm{j}} \mathrm{eps}_{\mathrm{jt}}+\beta_{4 \mathrm{j}} \text { flev }_{\mathrm{jt}}+\beta_{5 \mathrm{j}} \text { intcov }_{\mathrm{jt}}+\beta_{6 \mathrm{j}} \mathrm{EQ}_{\mathrm{jt}}+\varepsilon_{\mathrm{jt}}
$$

where $\mathrm{j}=1, \ldots, \mathrm{N}$ for each firm in the panel and $\mathrm{t}=1, \ldots, \mathrm{T}$ refers to the time period. Book values are considered important elements in reavealing substantial accounting information, especially for the future course of earnings (Burgstahler and Dichev, 1997). The importance of earnings-per-share measurement of earnings has been also exemplified for the accounting information value relevance (Ramakrishnan and Thomas, 1998). This type of information seems to be extremely important for capital market investors.

Table 4 displays the estimation results. The first panel displays the effect of the variable combosing the accounting information concept on wacc. In this model the coefficients are shown to have the expected signs, while they are all statistically significant at the one percent significance level. Looking at the model's overall performance, as reported by a battery of diagnostic tests, the estimated equation satisfies certain econometric criteria, namely absence of serial correlation (LM test), absence of functional misspecification (RESET test) and absence of heteroskedasticity (HE test). Focusing on the altenative measures of earnings quality we can infer that all four measures, given the interpretation provided above, exert a negative and statistically significant effect on the cost of capital. We interpret these findings as indicating that as the quality of earnings announcemtns decreases, so does the amount investors are willing to pay for a dollar of earnings, implying a higher cost of capital for firms with lower-quality earnings announcements.

\section{Insert Table 4 Here}

Once these estimations are available, the estimated wacc is saved. Next, Table 4 presents two versions of the panel data model that associates the estimated cost of capital and excess stock returns. In particular, the second panel displays the effect of the cost of capital on excess stock returns directly from the actual data and without taking into consideration any other accounting information. The results indicate that there exists a positive, albeit statistically insignificant, association between these two variables, which of course is in dispute. Once again, the performance of the model does not indicate any statistical anomaly. By contrast, in the third panel, the estimated cost of capital, i.e. the fitted values of wacc from the first panel of Table 4, which incorporates directly certain amounts of accounting information, is used and it is shown that it exerts a negative and statistically significant impact on excess stock returns. Four versions of this model are reported, associated with the four alternative earnings quality measures. The statistical performance of these models also displays a satisfactory picture. In all four versions the cost of capital exerts a negative impact on excess returns. This time, however, the explanatory performance in all four cases has extensively risen, from 0.39 to $0.53-0.89$. In addition, the size influence of the cost of capital on excess returns has also increased, implying that the components of accounting information tend to reveal an extensive component of accounting information, relevant to the stock market.

\section{Conclusions and Implications}

This paper showed empirically the links between accounting information, cost of capital and excess stock returns for a sample of 330 US manufacturing firms and the panel data methodological approach over the period 1990-2009. The empirical findings displayed that accounting information, as it is proxied by certain variables closely associated with each firm, affects directly the firm's cost of capital. This, in turn, implies that by incorporating all available pieces of information related to the accounting environment of the firm, tends to exert a negative effect on the firm's excess stock returns, an empirical documentation not captured in case that researchers attempt to direct link the cost of capital and excess stock returns. A possible explanation is based on the arguments that improved accounting 
information tends to affect the firm's real decisions. As a result, investors can assess better the future potential course of the firm, which has a direct effect on the future course of the firm's stock price.

With respect to earnings quality, the results lent support to the fact that asymmetric information poses risk to uninformed investors and should be reflected in the cost of capital. Moreover, the results also suggested the notion, popular both in the accounting literature and on Wall Street, that earnings have different 'qualities', has a great amount of truth to it. In other words, the fact that discretionary accruals, as a measure of earnings quality, imply that such quality measures are important proxies for firms' information environment. Therefore, our empirical findings indicate that investors cannot fully unravel discretionary accruals and such discretion serves to reduce the effectiveness of public earnings announcements as a device for resolving asymmetric information risk and mitigating gains to insiders that define that risk.

The above empirical findings have important implications for researchers, managers and policy makers. For researchers imply that an asset-pricing model without the earnings announcement quality factor not fully specified induces misspecification bias on the estimated coefficients and the empirical results turn out to be invalid. For managers they provide insights into the strategies they could follow to increase the extent to which stock prices impound their private information. If managers maintain a high quality reporting system, investors are more responsive to their disclosures performance. Thus, the empirical findings suggest that investors mitigate the risk of resource misallocation by conditioning their reliance on quality disclosures, i.e. on the firm's reported earnings quality, as well as on managerial incentives and corporate financing. Moreover, managers compensated with stock options have serious incentives to increase the degree of volatility during the expected time they are holding those stock options. According to the view that considers the firm's cost of capital as a proxy for return volatility, such stock options are a major incentive for managers to take actions leading to a higher cost of capital. In addition, the regulatory authorities have to make mandatory the disclosure of more accounting information, thus, leading to lower market risk premia and higher stock prices. Moreover, the results could also be taken seriously into consideration by practitioners, as a mean for better evaluation of accounting policies. Thus, various groups who are involved in this accounting system, as accountants, auditors and regulators and their goal is to improve to a great extent the quality of accounting information, should find those efficient mechanisms that will enable them to transmit such information to final investors and to disclose all possible information that will assist the entire system to lead to potential crises periods.

Finally, the implications of our empirical findings also extend the research on accounting choices. Shedding light on the interrelations between disclosures and reporting quality, between managerial incentives and the firms' information environment, and between financing on these choices and investor's decision making, it highlights the need for future research to examine firms' choises not in isolation, but as a part of a general reporting and disclosure equilibrium.

\section{Acknowlegements}

The authors wish to express their graditude to the Editor as well as to a referee of this journal whose comments increased the quality of this paper. Needless to say, the usual disclaimer applies.

\section{References}

Aboody, D., Hughes, J., \& Liu, J. (2005). Earnings Quality, Insider Trading, and Cost of Capital. Journal of Accounting Research, 43, 651-673.

Aboody, D., \& Lev, B. (2000). Information Asymmetry, R\&D and Insider Gains. Journal of Finance, 55(6), 2747-2766.

Alford, A., Jones, J., Leftwish, R., \& Zmijewski, M. (1993). The Relative Informativeness of Accounting Disclosures in Different Countries. Journal of Accounting Research, 31, 183-223. http://dx.doi.org/10.2307/2491170

Amihud, Y., \& Mendelson, H. (1986). Asset Pricing and the Bid-Ask Spread. Journal of Financial Economics, 17, 223-249. http://dx.doi.org/10.1016/0304-405X(86)90065-6

Amir, E., Harris, T., \& Venuti, E. (1993). A Comparison of the Value-Relevance of US versus non-US GAAP Accounting Measures Using Form 20-F Reconciliations. Journal of Accounting Research, 31, 230-264. http://dx.doi.org/10.2307/2491172

Arellano, M., \& Bond, S. (1991). Some Tests of Specification for Panel Data: Monte Carlo Evidence and an Application to Employment Equations. Review of Economics Studies, 58, 277-297. http://dx.doi.org/10.2307/2297968 
Baiman, S., \& Verrecchia, R. (1996). The Relation Among Capital markets, Financial Disclosure, Production Efficiency, and Insider Trading. Journal of Accounting Research, 34, 1-22. http://dx.doi.org/10.2307/2491329

Baltagi, B. H. (2001). Econometric Analysis of Panel Data, $2^{\text {nd }}$ Edition. New York: Wiley.

Barth, M. E., \& Clinch, G. (1996). International Accounting Differences and Their Relation to Share Prices: Evidence from UK, Australian, and Canadian Firms. Contemporary Accounting Research, 13, 135-170. http://dx.doi.org/10.1111/j.1911-3846.1996.tb00495.x

Beaver, W. H., \& Landsman, W. R. (1998). Relative Valuation Roles of equity Book Value and Net Income as a Function of Financial Health. Journal of Accounting and Economics, 25, 1-34. http://dx.doi.org/10.1016/S0165-4101(98)00017-2

Beaver, W., Clarke, R., \& Wright, W. (1979). The Association Between Unsystematic Security Returns and the Magnitude of Earnings Forecast Errors. Journal of Accounting Research, 17, 316-340. http://dx.doi.org/10.2307/2490507

Beneish, M., \& Vargus, M. (2002). Insider Trading, Earnings Quality and Accrual Mispricing. The Accounting Review, 77, 755-793. http://dx.doi.org/10.2308/accr.2002.77.4.755

Burgstahler, D., \& Dichev, I. (1997). Earnings, Adaptations and Equity Value. The Accounting Review, 187-215.

Chan, K. C., Chan, L., Jegadesh, N., \& Lakonishok, J. (2001). Accruals Quality and Stock Returns; The Evidence from Accruals. Working Paper, National Taiwan University and University of Illinois.

Chan, K. C., \& Seow, G. S. (1996). The Association Between Stock Returns and Foreign GAAP Earnings Versus Earnings Adjusted to US GAAP. Journal of Accounting Economics, 21, 139-158. http://dx.doi.org/10.1016/0165-4101(95)00405-X

Cohen, D. (2003). Quality of Financial Reporting Choice: Determinants and Economic Consequences. Working Paper, Northwestern University.

Collins, D., Kothari, S., \& Rayburn, J. (1989). An Analysis of Intertemporal and Cross- Sectional Determinants of Earnings Response Coefficients. Journal of Accounting and Economics, 11, 143-181. http://dx.doi.org/10.1016/0165-4101(89)90004-9

Dechow, P., \& Dichev, I. (2002). The Quality of Accruals and Earnings: The Role of Accrual Estimation Errors. The Accounting Review, 11, 35-59. http://dx.doi.org/10.2308/accr.2002.77.s-1.35

Demers, E., \& Vega, C. (2009). Soft Information in Earnings Announcements: News or Noise?. Working Paper at SSRN: http://ssrn.com/abstract=1153450.

Dow, J., \& Gorton, G. (1995). Profitable Informed Trading in a Simple General Equilibrium Model of Asset Pricing. Journal of Economic Theory, 67, 327-369. http://dx.doi.org/10.1006/jeth.1995.1077

Dye, R. (1985). Disclosure of Non-Proprietary Information. Journal of Accounting Research, 23, 123-145. http://dx.doi.org/10.2307/2490910

Easley, D., \& O'Hara, M. (2004). Information and the Cost of Capital. Journal of Finance, 59, 1553-1589. http://dx.doi.org/10.1111/j.1540-6261.2004.00672.x

Easley, D., Hvidkjaer, S., \& O'Hara, M. (2002). Is Information Risk a Determinant of Asset Returns?. Journal of Finance, 57, 2185-2221. http://dx.doi.org/10.1111/1540-6261.00493

Ecker, F., Francis, J., Kim, I., Olsson, P. M., \& Schipper, K. (2006). A Returns-Based Representation of Earnings Quality. The Accounting Review, 81, 749-780. http://dx.doi.org/10.2308/accr.2006.81.4.749

Fama, E., \& French, K. (1996), Multifactor Explanations of Asset Pricing Anomalies. Journal of Finance, 51, 55-84. http://dx.doi.org/10.2307/2329302

Francis, J., Nanda, D., \& Olsson, P. (2008). Voluntary Disclosure, Earnings Quality and the Cost of Capital. Journal of Accounting Research, 46, 53-99. http://dx.doi.org/10.1111/j.1475-679X.2008.00267.x

LaFond, R., Olsson, P., \& Schipper, K. (2002). The Market Pricing of Earnings Quality. Working Paper, Duke University.

Graham, R., \& King, R. (1998). The Relation of Firm Market Values with Book Values and Residual Accounting Earnings in Six asian Countries. Working Paper, Oregon State University.

Hadri, K. (2000). Testing for Stationarity in Heterogeneous Panel Data. Econometric Journal, 3, 148-161. http://dx.doi.org/10.1111/1368-423X.00043 
Hayn, C. (1995). The Information Content of Losses. Journal of Accounting and Economics, 20, 125-153.

Holtz-Eakin, D. (1986). Testing for Individual Effects in Dynamic Models Using Panel Data. NBER Technical Paper Series", No. 57.

Newey, W., \& Rosen, H. (1985). Implementing Causality Tests with Panel Data with an Example from Local Public Finance. NBER Technical Working Paper, No. 48.

Hsiao, C. (2003). Analysis of Panel Data, $2^{\text {nd }}$ Edition. Cambridge: Cambridge University Press. http://dx.doi.org/10.1017/CBO9780511754203

Hussainey, K., Schleicher, T., \& Walker, M. (2003). Undertaking Large-Scale Disclosure Studies when AIMR-FAF Ratings are not Available: The Case of Prices Leading Earnings. Accounting and Business Research, 33, 275-294.

Im, K. S., Pesaran, M. H., \& Shin, Y. (2003). Testing for Unit Roots in Heterogeneous Panels. Journal of Econometrics, 115, 53-74.

Imhoff, E. (1978). The Representativeness of Management Earnings Forecasts. The Accounting Review, 53, 836-850. http://dx.doi.org/10.1016/S0304-4076(03)00092-7

Jones, J. (1991). Earnings Management During Import Relief Investigation. Journal of Accounting Research, 29, 193-228. http://dx.doi.org/10.2307/2491047

Lang, M., \& Lundholm, R. (1993). Cross-Sectional Determinants of Analyst Ratings of Corporate Disclosures. Journal of Accounting Research, 31, 246-271. http://dx.doi.org/10.2307/2491273

Levin, R., Lin, C. F., \& Chu, C. (2002). Unit Root Tests in Panel Data: Asymptotic and Finite-Sample Properties. Journal of Econometrics, 108, 1-24. http://dx.doi.org/10.1016/S0304-4076(01)00098-7

Maddala, G. S., \& Wu, S. (1999). A Comparative Study of Unit Root Tests with Panel Data and a New Simple Test. Oxford Bulleting of Economics and Statistics, 61, 631-652. http://dx.doi.org/10.1111/1468-0084.61.s1.13

Ohlson, J. (1995). Earnings, Book alues, and Dividends in Equity Valuation. Contemporary Accounting Research, 661-687. http://dx.doi.org/10.1111/j.1911-3846.1995.tb00461.x

Ramakrishnan, R., \& Thomas, J. (1998). Valuation of Permanent, Transitory, and Price-Irrelevant Components of Reported Earnings. Journal of Accounting, Auditing and Finance, 13, 301-336.

Sargan, J. D. (1958). The Estimation of Economic Relationships Using Instrumental Variables. Econometrica, 26, 393-415. http://dx.doi.org/10.2307/1907619

Spiegel, M., \& Subrahmanyam, A. (1992). Informed Speculation and Hedging in a Non-Competitive Securities Market. Review of Financial Studies, 5, 307-330. http://dx.doi.org/10.1093/rfs/5.2.307

Verrecchia, R. E. (1990). Information Quality and Discretionary Disclosure. Journal of Accounting and Economics, 12, 365-380. http://dx.doi.org/10.1016/0165-4101(90)90021-U

Verrecchia, R. E. (1983). Discretionary Disclosure. Journal of Accounting and Economics, 5, 179-194. http://dx.doi.org/10.1016/0165-4101(83)90011-3

Waymire, G. (1985). Earnings Volatility and Voluntary Management Forecast Disclosures. Journal of Accounting Research, 23, 268-295. http://dx.doi.org/10.2307/2490919

Xie, H. (2001). The Mispricing of Abnormal Accruals. The Accounting Review, 76, 357-373. http://dx.doi.org/10.2308/accr.2001.76.3.357 
Table 1. Panel Unit Root Tests

\begin{tabular}{|c|c|c|}
\hline \multicolumn{3}{|c|}{ IPS Panel Unit Root Tests } \\
\hline Variables & Without Trend & With Trend \\
\hline $\mathrm{b}$ & $-1.47(3)$ & $-1.68(3)$ \\
\hline$\Delta \mathrm{b}$ & $-5.11(2)^{*}$ & $-5.41(1)^{*}$ \\
\hline er & $-5.10(2)^{*}$ & $-5.57(2)^{*}$ \\
\hline bv & $-1.25(3)$ & $-1.47(3)$ \\
\hline$\Delta \mathrm{bv}$ & $-5.07(2)^{*}$ & $-5.38(2)^{*}$ \\
\hline eps & $-5.43(2)^{*}$ & $-5.86(3)^{*}$ \\
\hline flev & $-1.67(3)$ & $-1.84(3)$ \\
\hline$\Delta$ flev & $-4.87(2)^{*}$ & $-5.11(2)^{*}$ \\
\hline intcov & $-1.63(3)$ & $-1.92(3)$ \\
\hline$\Delta$ intcov & $-4.51(2)^{*}$ & $-4.94(2)^{*}$ \\
\hline TA/Asset & $-5.43(3)^{*}$ & $-5.68(3)^{*}$ \\
\hline $1 /$ Asset & $-1.19(4)$ & $-1.42(3)$ \\
\hline$\Delta(1 /$ Asset $)$ & $-4.76(2)^{*}$ & $-4.93(2)^{*}$ \\
\hline$\Delta$ REV/Asset & $-4.78(3)^{*}$ & $-5.23(2)^{*}$ \\
\hline PPE/Asset & $-4.52(3)^{*}$ & $-5.03(2)^{*}$ \\
\hline TCA/Asset & $-4.61(3)^{*}$ & $-4.88(2)^{*}$ \\
\hline TCA/AvAsset & $-4.49(2)^{*}$ & $-4.71(2)^{*}$ \\
\hline $\mathrm{CF} / \mathrm{AvAsset}$ & $-4.74(2)^{*}$ & $-5.11(2)^{*}$ \\
\hline EQ1 & $-5.23(2)^{*}$ & $-5.48(1)^{*}$ \\
\hline EQ2 & $-4.89(1)^{*}$ & $-5.18(1)^{*}$ \\
\hline EQ3 & $-4.33(2)^{*}$ & $-4.61(2)^{*}$ \\
\hline EQ4 & $-4.39(1)^{*}$ & $-4.73(1)^{*}$ \\
\hline wacc & $-5.09(2)^{*}$ & $-5.33(2)^{*}$ \\
\hline wacc1 (EQ1) & $-4.85(2)^{*}$ & $-5.13(1)^{*}$ \\
\hline wacc2 (EQ2) & $-4.92(2)^{*}$ & $-5.22(1)^{*}$ \\
\hline wacc3 (EQ3) & $-5.10(1)^{*}$ & $-5.31(1)^{*}$ \\
\hline wacc4 (EQ4) & $-4.73(2)^{*}$ & $-4.93(1)^{*}$ \\
\hline \multicolumn{3}{|c|}{ LLC Panel Unit Root Tests } \\
\hline Variables & With Trend & \\
\hline $\mathrm{b}$ & -1.32 & \\
\hline$\Delta \mathrm{b}$ & $-9.53^{*}$ & \\
\hline er & $-8.75^{*}$ & \\
\hline bv & -1.62 & \\
\hline$\Delta \mathrm{bv}$ & $-9.37 *$ & \\
\hline eps & $-4.73^{*}$ & \\
\hline flev & -1.72 & \\
\hline$\Delta$ flev & $-4.71^{*}$ & \\
\hline intcov & -1.50 & \\
\hline$\Delta$ intcov & $-4.48^{*}$ & \\
\hline TA/Asset & $-8.33 *$ & \\
\hline $1 /$ Asset & -1.34 & \\
\hline$\Delta(1 /$ Asset $)$ & $-6.93 *$ & \\
\hline$\Delta$ REV/Asset & $-7.18 *$ & \\
\hline PPE/Asset & $-7.26^{*}$ & \\
\hline TCA/Asset & $-6.31^{*}$ & \\
\hline TCA/AvAsset & $-6.40 *$ & \\
\hline CF/AvAsset & $-5.54 *$ & \\
\hline EQ1 & $-6.73 *$ & \\
\hline EQ2 & $-8.29 *$ & \\
\hline EQ3 & $-6.32 *$ & \\
\hline EQ4 & $-6.55^{*}$ & \\
\hline wacc & $-7.68 *$ & \\
\hline
\end{tabular}




\begin{tabular}{|c|c|}
\hline wacc1 (EQ1) & $-6.89 *$ \\
\hline wacc2 (EQ2) & $-6.90 *$ \\
\hline wacc3 (EQ3) & $-7.24 *$ \\
\hline wacc4 (EQ4) & $-7.14 *$ \\
\hline \multicolumn{2}{|c|}{ Handri (hom) Panel Unit Root Tests } \\
\hline Variables & With Trend \\
\hline $\mathrm{b}$ & $11.27^{*}$ \\
\hline$\Delta \mathrm{b}$ & 1.35 \\
\hline er & 1.17 \\
\hline bv & $19.85^{*}$ \\
\hline$\Delta \mathrm{bv}$ & 1.13 \\
\hline eps & 1.26 \\
\hline flev & 1.83 \\
\hline$\Delta$ flev & $4.55^{*}$ \\
\hline intcov & 1.82 \\
\hline$\Delta$ intcov & $4.83 *$ \\
\hline TA/Asset & 1.21 \\
\hline 1/Asset & $18.25^{*}$ \\
\hline$\Delta(1 /$ Asset $)$ & 1.13 \\
\hline$\Delta$ REV/Asset & 1.48 \\
\hline PPE/Asset & 1.16 \\
\hline TCA/Asset & 1.52 \\
\hline TCA/AvAsset & 1.23 \\
\hline CF/AvAsset & 1.14 \\
\hline EQ1 & 1.12 \\
\hline EQ2 & 1.32 \\
\hline EQ3 & 1.06 \\
\hline EQ4 & 1.15 \\
\hline wacc & 1.44 \\
\hline wacc1 (EQ1) & 1.37 \\
\hline wacc2 (EQ2) & 1.18 \\
\hline wacc3 (EQ3) & 1.25 \\
\hline wacc4 (EQ4) & 1.21 \\
\hline \multicolumn{2}{|c|}{ Handri (het) Panel Unit Root Tests } \\
\hline Variables & With Trend \\
\hline $\mathrm{b}$ & $8.48^{*}$ \\
\hline$\Delta \mathrm{b}$ & 0.62 \\
\hline er & 1.77 \\
\hline bv & $18.36^{*}$ \\
\hline$\Delta \mathrm{bv}$ & 1.47 \\
\hline eps & 1.54 \\
\hline flev & 1.64 \\
\hline$\Delta$ flev & $4.56^{*}$ \\
\hline intcov & 1.56 \\
\hline$\Delta$ intcov & $4.81^{*}$ \\
\hline TA/Asset & 1.13 \\
\hline 1/Asset & $10.95^{*}$ \\
\hline$\Delta(1 /$ Asset $)$ & 1.03 \\
\hline$\Delta$ REV/Asset & 1.16 \\
\hline PPE/Asset & 1.41 \\
\hline TCA/Asset & 1.15 \\
\hline TCA/AvAsset & 1.23 \\
\hline $\mathrm{CF} /$ AvAsset & 1.24 \\
\hline EQ1 & 0.78 \\
\hline
\end{tabular}




\begin{tabular}{ll}
\hline EQ2 & 0.84 \\
EQ3 & 1.02 \\
EQ4 & 0.83 \\
wacc & 1.18 \\
wacc1 (EQ1) & 1.23 \\
wacc2 (EQ2) & 0.91 \\
wacc3 (EQ3) & 1.14 \\
wacc4 (EQ4) & 1.52
\end{tabular}

Fisher-ADF

Variables

b

$\Delta \mathrm{b}$

er

bv

$\Delta \mathrm{bv}$

eps

flev

$\Delta$ flev

intcov

$\Delta$ intcov

TA/Asset

1/Asset

$\Delta(1 /$ Asset $)$

$\triangle$ REV/Asset

PPE/Asset

TCA/Asset

TCA/AvAsset

$\mathrm{CF} /$ AvAsset

EQ1

EQ2

EQ3

EQ4

wacc

wacc1 (EQ1)

wacc2 (EQ2)

wacc3 (EQ3)

wacc4 (EQ4)

Fisher-PP

Variables

b

$\Delta \mathrm{b}$

er

bv

$\Delta \mathrm{bv}$

eps

flev

$\Delta$ flev

intcov

$\Delta$ intcov

TA/Asset

1/Asset

$\Delta$ (1/Asset)

$\triangle$ REV/Asset

PPE/Asset
15.68

$94.55 *$

$118.33 *$

21.23

131.98*

$164.95 *$

31.09

152.84*

28.58

164.90*

$131.10^{*}$

11.15

$132.23 *$

$125.41 *$

145.64*

$133.12^{*}$

128.94*

126.74*

$136.29 *$

130.20 *

121.76*

$137.15^{*}$

$141.23 *$

$137.66^{*}$

141.58*

141.84*

$138.19^{*}$

21.26

132.48*

$147.89 *$

25.48

142.18*

$154.81 *$

24.93

$144.07 *$

31.83

$167.18^{*}$

$145.77^{*}$

10.14

$122.67^{*}$

$129.81 *$

$142.07^{*}$ 


\begin{tabular}{ll}
\hline TCA/Asset & $131.66^{*}$ \\
TCA/AvAsset & $132.84^{*}$ \\
CF/AvAsset & $129.85^{*}$ \\
EQ1 & $134.19^{*}$ \\
EQ2 & $138.44^{*}$ \\
EQ3 & $128.57 *$ \\
EQ4 & $133.22^{*}$ \\
wacc & $141.15^{*}$ \\
wacc1 (EQ1) & $132.96^{*}$ \\
wacc2 (EQ2) & $145.82^{*}$ \\
wacc3 (EQ3) & $134.69^{*}$ \\
wacc4 (EQ4) & $133.44 *$ \\
\hline
\end{tabular}

Numbers in parentheses are the augmented lags included in the unit root test, while $\Delta$ denotes first differences. ${ }^{*}$ denotes statistical significance at $1 \%$

Table 2. Tests of Dynamic Heterogeneity Across Groups

\begin{tabular}{lllc}
\hline Specification & $\operatorname{ADF}(3)$ & $\mathrm{AR}(3)$ & White's Test \\
\hline $\begin{array}{l}\text { wacc- } \Delta \mathrm{b}-\Delta \mathrm{bv}- \\
\text { eps- } \Delta \text { flev- } \Delta \text { intcov-EQ1 }\end{array}$ & $35.02^{*}$ & $41.55^{*}$ & $69.63^{*}$ \\
& & & \\
wacc- $\Delta \mathrm{b}-\Delta$ bv- & & & \\
eps- $\Delta$ flev- $\Delta$ intcov-EQ2 & $37.54^{*}$ & $44.72^{*}$ & $8.31^{*}$ \\
& & & \\
wacc- $\Delta \mathrm{b}-\Delta$ bv- & & & \\
eps- $\Delta$ flev- $\Delta$ intcov-EQ3 & $38.11^{*}$ & $45.43^{*}$ & $76.82^{*}$ \\
& & & \\
wacc- $\Delta \mathrm{b}-\Delta \mathrm{bv}-$ & & & \\
eps- $\Delta$ flev- $\Delta$ intcov-EQ4 & $31.12^{*}$ & $40.42^{*}$ & $63.46^{*}$ \\
er-wacc & $27.09^{*}$ & $30.14^{*}$ & $61.74^{*}$ \\
er-wacc1 (EQ1) & $29.49^{*}$ & $37.88^{*}$ & $66.53^{*}$ \\
er-wacc1 (EQ2) & $35.77^{*}$ & $40.91^{*}$ & $70.23^{*}$ \\
er-wacc1 (EQ3) & $32.05^{*}$ & $36.55^{*}$ & $67.81^{*}$ \\
er-wacc1 (EQ4) & $34.64^{*}$ & $38.82^{*}$ & $68.77^{*}$ \\
\hline
\end{tabular}

$\mathrm{ADF}(3)$ reports the parameter equality test (F-test) across all relationships in the panel. AR(3) displays the F-test of parameter equality conducted in a third-order autoregressive model of the relationships. White's test reports the White's test of equality of variances across the investigated relationships in the panel. $\Delta$ denotes first differences. $*$ denotes statistical significance at $1 \%$.

Table 3. Correlations Among Earnings-Quality Measures

\begin{tabular}{lllll}
\hline & EQ1 & EQ2 & EQ3 & EQ4 \\
EQ1 & & 0.68 & 0.42 & 0.37 \\
EQ2 & 0.72 & & 0.45 & 0.40 \\
EQ3 & 0.44 & 0.48 & & 0.27 \\
EQ4 & 0.39 & 0.41 & 0.30 & \\
\hline
\end{tabular}

Spearman correlations are above diagonal, while Pearson correlations are below diagonal 
Table 4. Panel (Fixed Effects) Regression Estimates

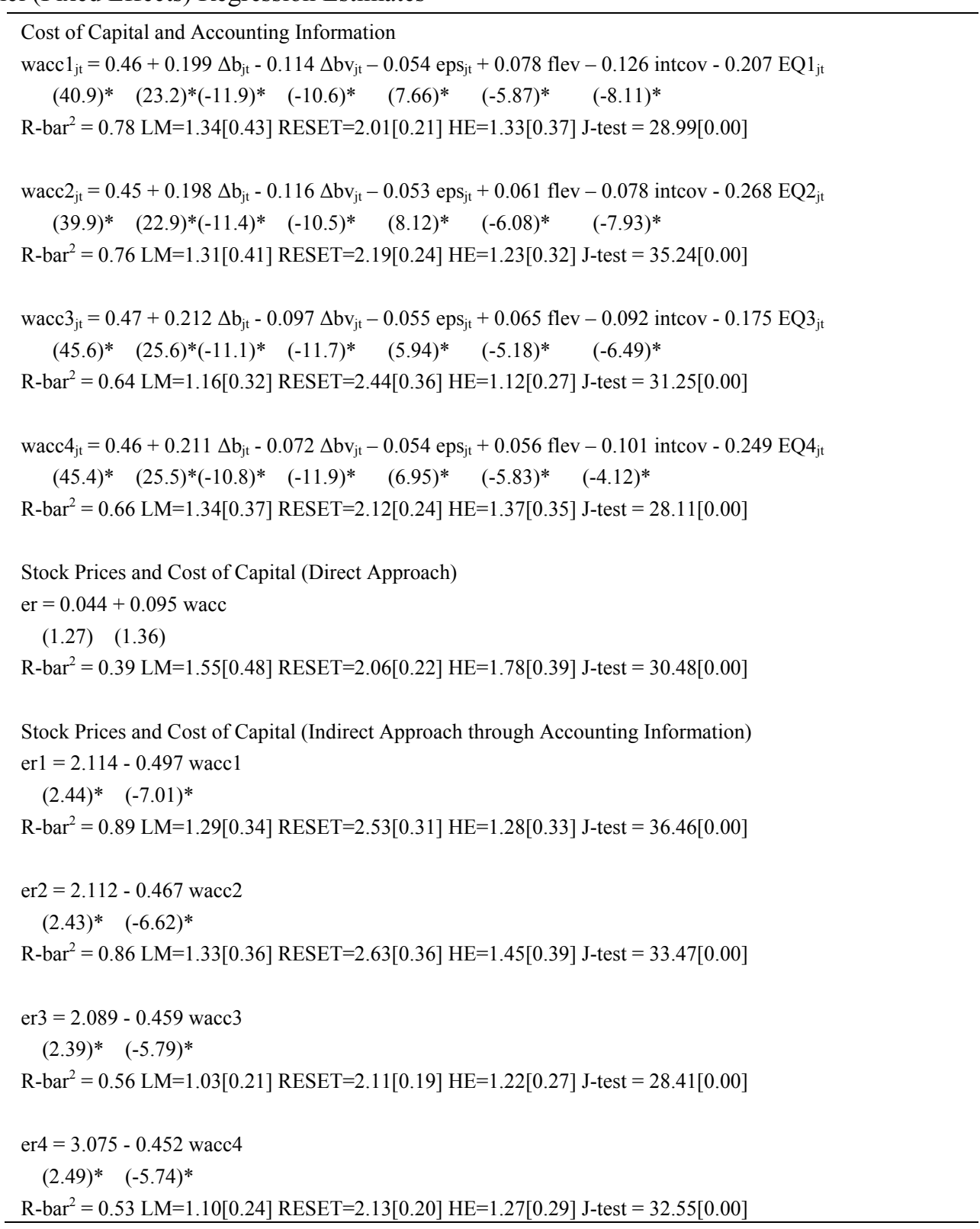

$\mathrm{t}$-statistics are reported in parentheses, while p-values are reported in brackets. LM is a serial correlation for the residuals test, RESET is a model specification test, HE is a heteroskedasticity test and J-test is the Sargan's instruments validity test. $\Delta$ denotes first differences. * denotes significance at $1 \%$. 